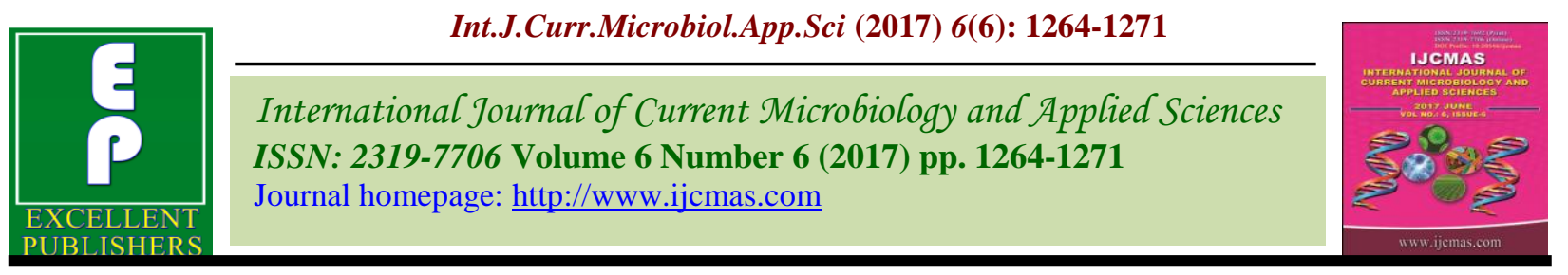

Original Research Article

https://doi.org/10.20546/ijcmas.2017.606.148

\title{
Nutritional Evaluation of Indigenously Developed Weaning Food from Malted Sorghum Incorporated with Soybean and Raw Banana Flour
}

\author{
Varsha Kumari*, Sangeeta C. Sindhu and Jyoti Singh \\ Department of Foods and Nutrition, CCSHAU Hisar, Haryana, India \\ *Corresponding author
}

A B S T R A C T

Keywords

Weaning food, malting, Blanching, sensory analysis, Malted sorghum, Banana flour, Viscosity, Total lysine, Nutritional analysis.

\section{Article Info}

Accepted:

19 May 2017

Available Online:

10 June 2017
Composite flours were developed using malted sorghum, blanched soybean and blanched banana flours in three different ratios, viz. 60:20:20; 50:30:20 and 40:30:30 respectively. Weaning foods were developed by adding $80 \mathrm{~g}$ of either skim or whole milk powder and $48 \mathrm{~g}$ of sugar per hundred grams in each of composite flour. This developed mixture, when cooked in $800 \mathrm{ml}$ of water resulted in weaning foods of acceptable consistency. The weaning foods thus obtained were found to be acceptable to judges. Based on mean scores of sensory evaluation obtained, one most acceptable weaning food was selected for further analysis. The developed weaning food was acceptable to lactating mothers and had a good nutrient profile. Crude protein, crude fat and crude fibre and ash content were 19.94, 16.05, 2.83 and $2.98 \mathrm{~g} / 100 \mathrm{~g}$, respectively while total carbohydrate was found to be $58.14 \mathrm{~g} / 100 \mathrm{~g}$ and energy was $457.19 \mathrm{kcal}$.

\section{Introduction}

Milk alone cannot meet baby's nutritional requirements beyond six months of age. Easy to digest supplements are required along with mother's milk until the child is ready to eat adult foods. This is a transitional phase from mother's feed to adult food. Protein- Energy Malnutrition (PEM) generally occurs during this crucial transitional phase when children are being weaned from liquid (i.e. breast milk) to semi-solid or fully adult (family) foods. According to UNICEF, most lethal forms of malnutrition include Protein energy malnutrition, "the silent emergency of the world" which may have hunted mankind since the dawn of history. Every year 1 million children below the age of five years die due to malnutrition related causes in India alone. This gives room for the introduction of complementary foods that can meet the nutritional requirements of the growing child (Ikujenlola and Fashakin, 2005). Complementary food is the food given to infants along with breast milk to ensure proper nutrition.

Good quality weaning food must have high nutrient density, low viscosity, low bulk density and appropriate texture along with high energy, protein and micronutrient contents. It should have a consistency that 
allows easy consumption (Balasubramanian et al., 2014). The traditional complementary foods are often associated with high viscosity which may cause choking and suffocation of infant during feeding.

The millets and pulses have the potential to alleviate food related factors of malnutrition, particularly among weaning age children. Cereals are generally deficient in lysine but have sufficient sulphur containing amino acids which are limiting factors in legumes whereas legumes are known to be rich in lysine (Cole et al., 2016). Processing techniques used for formulating complementary foods such as soaking, sprouting, fermentation and roasting enhance the bioavailability of micronutrients by decreasing the antinutritional factors and improving overall digestibility and absorption of nutrients.

Such processing techniques also reduce the high bulk of complementary food by reducing the viscosity (Rasane et al., 2015). Sorghum is excellent source of protein, minerals, fibre and phytochemicals (Dykes and Rooney, 2007). Malting can further improve the protein and starch digestibilities (Agu and Palmer, 1997; Rooney et al., 2000). Like every other cereal, it is ideal to combine sorghum with legume as this will improve their nutritive value. Soybean has long been recognized as an excellent source of high quality protein. Soybean has great potential in overcoming protein calorie malnutrition because it contains 38 to 40 per cent protein and 18 to 20 per cent fat (Rastogi and Singh, 1989; Bhatia and Greer, 2008). Bananas are rich in vitamin B6 and they are a good source of fiber, vitamin $\mathrm{C}$, magnesium and potassium (Zhang et al., 2005). The present work was designed to develop weaning foods using sorghum based composite mixtures. The process of malting and blanching were applied to improve the nutritive value and digestibility.

\section{Materials and Methods}

The grain samples of sorghum HJ 541 was procured from Forage and Pulses Sections of Deptt. of Genetics and Plant Breeding, CCSHAU, Hisar. Soybean and unripe banana was procured in a single lot from local market.

\section{Processing of grains}

Malting of Sorghum was done according to the modified method of Kulkarni et al., (1984). The grains were steeped (sorghum: water: $1: 3 \mathrm{w} / \mathrm{v}$ ) for 7,6 and 5 hours with intermittent aeration period of 2 hours each. Total steeping period was 18 hours. The steeped air dried seeds were allowed to germinate in an incubator at $25-30^{\circ} \mathrm{C}$ for 48 hours. The germinated grains were kilned in hot air oven at $65^{\circ} \mathrm{C}$ for 18 hours and devegetated by abrasive action.

For blanching, soybean seeds were kept in boiling water for 30 minutes. Blanched seeds were then drained, dehulled and spread on sheets in hot air oven maintained at $65{ }^{\circ} \mathrm{C}$ for $6-8$ hours. Dried seeds were grounded in an electric grinder (Cyclotec, M/s Tecator, Hoganas, Sweden). The flour thus obtained was sieved through 60 mesh sieve.

Raw banana was peeled and sliced to thickness of $2 \mathrm{~mm}$. The sliced raw bananas were kept in boiling water for 10 minutes (modified method of Mishra et al., 2014). Blanched slices were drained and spread on sheets in hot air oven maintained at $65^{\circ} \mathrm{C}$ for 6-8 hours. Dried slices were grounded in an electric grinder (Cyclotec, M/s Tecator, Hoganas, Sweden). The flour thus obtained was sieved through 60 mesh sieve.

\section{Development of composite flours}

Three composite flours were formulated using malted sorghum, blanched soybean and 
blanched banana flour in different proportions. The following composite flours were developed:

CF I Sorghum flour:Soybean flour:Banana flour $(60: 20: 20 ; \mathrm{w} / \mathrm{w})$

CF II Sorghum flour:Soybean flour:Banana flour $(50: 30: 20 ; \mathrm{w} / \mathrm{w})$

CF III Sorghum flour:Soybean flour:Banana flour $(40: 30: 30 ; w / w)$

\section{Development of weaning foods}

The composite flours were used as base to develop weaning foods. One hundred gram of each of composite flour was cooked with 80 gm of skimmed/whole milk powder and 48 gm of grounded sugar.

\section{Organoleptic evaluation}

The food mixtures cooked with $80 \mathrm{~g}$ of skim/whole milk powder, $800 \mathrm{ml}$ water and $48 \mathrm{~g}$ of sugar were subjected to sensory evaluation on a 9 point hedonic scale by a panel of 10 judges based on sensory attributes i.e. colour, appearance, aroma, texture, taste and overall acceptability. On the basis of mean scores of sensory evaluation obtained, one best weaning foods was selected and subjected to organoleptic evaluation by lactating mothers. This selected weaning food was studied for nutritional composition as well.

\section{Nutritional evaluation}

The developed, most acceptable weaning food was analysed for Proximate composition (AOAC, 2000), total carbohydrate (by addition method), total soluble sugars (Yemm and Willis, 1954), reducing sugars (Somogyi, 1945), non -reducing sugars (by difference) and starch (Clegg, 1956). In vitro protein (Mertz et al., 1983) and Starch digestibility (Singh et al., 1982) was also determined.
Total iron, zinc, calcium and phosphorus in acid digested samples were determined by the atomic absorption spectrophotometer (Lindsey and Norwell, 1969). Mineral $\mathrm{HCl}$ extractability (Peterson et al., 1943), total lysine (Miyahara and Jikoo, 1967) and Viscosity (RVA, New port scientific U.K) were also studied.

\section{Statistical analysis}

The data were statistically analysed in complete randomized design for analysis of variance, mean, standards deviation and critical difference according to the standard methods (Sheoran and Pannu, 1998).

\section{Results and Discussion}

Table 1 presents the sensory scores of developed weaning food with skimmed and whole milk powder. The mean scores of 'colour' for weaning food with skimmed milk powder ranged from 7.10 (CF II) to 7.50 (CF I). The scores for 'appearance' were 7.80, 6.50 and 6.90 , respectively. The mean scores for 'aroma' of weaning food with skimmed milk powder were judged to vary from "liked slightly" to "like moderately". The scores for 'texture' for weaning food with skimmed milk powder were 7.60, 6.30 and 6.80, respectively for CF I, CF II and CF III. The mean scores for 'taste' of weaning food with skimmed milk were under the category "liked slightly" to "liked moderately". However, "overall acceptability scores" for CF I, CF II and CF III (with skimmed milk powder) were 7.64, 6.58 and 6.80, respectively. The mean sensory scores for 'colour' of CF I, CF II and CF III with whole milk powder were 7.60, 7.90 and 7.90 and were categorised as "like moderately" to "like very much". The scores for 'appearance' ranged from 7.60 (CF II) to 8.10 (CF III). The mean sensory scores for 'aroma' fell in the category of "like moderately" to "like very much". The scores 
for "texture" of CF I, CF II and CF III were $7.80,7.70$ and 7.90 , respectively. The mean scores for "taste" ranged from 7.70 to 8.50 (CF I and CF II) with whole milk powder.

Based on sensory analysis by panellists, CFIII was chosen for further sensory evaluation by by lactating mothers and was found to be acceptable. Scores for 'colour' were 7.20 which fell under the category of "liked moderately". 'Appearance' and aroma scores were 7.30 and 7.10 respectively. Scores for texture and taste were 6.90 and fell in the category of "liked moderately". Overall acceptability score was 7.08 and was found to be "liked moderately" by lactating mothers (Fig. 1).

Table 2 presents the chemical composition of CFIII based weaning food. Moisture content was 67.56 per cent. Crude protein, crude fat and crude fibre and ash content were 19.94, $16.05,2.83$ and $2.98 \mathrm{~g} / 100 \mathrm{~g}$, respectively while total carbohydrate was found to be $58.14 \mathrm{~g} / 100 \mathrm{~g}$ and energy was $457.19 \mathrm{kcal}$. Total soluble sugars, reducing sugars, nonreducing sugars and starch were $11.40,5.32$,
6.08 and $20.21 \mathrm{~g} / 100 \mathrm{~g}$, respectively. Starch digestibility was found to be $55.55 \mathrm{mg}$ maltose released/g while protein digestibility was 67.56 per cent. Total phosphorus, calcium, iron and zinc were 383.01, 481.02, 8.79 and $1.61 \mathrm{mg} / 100 \mathrm{~g}$, respectively. The content of $\mathrm{HCl}$ extractable mineral with respect to phosphorus, calcium, iron and zinc were $367.66,394.66,8.59$ and $1.19 \mathrm{mg} / 100 \mathrm{~g}$ respectively. Per cent extractability was found to be $95.82,82.04,97.72$ and 74.07 respectively for phosphorus, calcium, iron and zinc. Total lysine was $10.31 \mathrm{~g} / 16 \mathrm{~g}$ N. The gruel had a viscosity of $193.66 \pm 3.48 \mathrm{cp}$.

In the present study, malted sorghum based composite flours were developed using blanched soybean flours and blanched banana flour. A number of workers have previously reported development of cereal-pulsefruit/vegetable blends for complementary feeding. Obatolu and Cole (2000) prepared the complementary blends namely, malted maize/soybean blend (MS), unmalted maize/soybean blend (UMS), malted maize/cowpea blend (MC) and unmalted maize/cowpea blend (UMC).

Table.1 Sensory evaluation of developed weaning food (\% dry weight basis)

\begin{tabular}{|c|c|c|c|c|c|c|}
\hline $\begin{array}{c}\text { Weaning } \\
\text { Food }\end{array}$ & Colour & Appearance & Aroma & Texture & Taste & $\begin{array}{c}\text { Overall } \\
\text { acceptability }\end{array}$ \\
\hline \multicolumn{7}{|c|}{ Constituted with Skimmed milk powder } \\
\hline CF I & $7.50 \pm 0.16$ & $7.80 \pm 0.20$ & $7.50 \pm 0.16$ & $7.60 \pm 0.22$ & $7.80 \pm 0.20$ & $7.64 \pm 0.51$ \\
\hline CF II & $7.10 \pm 0.10$ & $6.50 \pm 0.16$ & $6.40 \pm 0.26$ & $6.30 \pm 0.30$ & $6.30 \pm 0.15$ & $6.58 \pm 0.08$ \\
\hline CF III & $7.30 \pm 0.15$ & $6.90 \pm 0.27$ & $6.90 \pm 0.18$ & $6.80 \pm 0.35$ & $6.20 \pm 0.29$ & $6.80 \pm 0.10$ \\
\hline \multicolumn{7}{|c|}{ Constituted with Whole milk powder } \\
\hline CF I & $7.60 \pm 0.22$ & $7.80 \pm 0.24$ & $7.40 \pm 0.30$ & $7.80 \pm 0.29$ & $7.70 \pm 0.30$ & $7.66 \pm 0.23$ \\
\hline CF II & $7.90 \pm 0.27$ & $7.60 \pm 0.34$ & $7.80 \pm 0.24$ & $7.70 \pm 0.30$ & $8.00 \pm 0.29$ & $7.80 \pm 0.25$ \\
\hline CF III & $7.90 \pm 0.27$ & $8.10 \pm 0.31$ & $8.84 \pm 0.26$ & $7.90 \pm 0.31$ & $8.50 \pm 0.26$ & $8.20 \pm 0.27$ \\
\hline
\end{tabular}

Values are mean \pm SE of ten independent determination 
Table.2 Chemical composition of developed weaning food (\% dry weight basis)

\begin{tabular}{|c|c|}
\hline Component & Content \\
\hline \multicolumn{2}{|l|}{ Proximate Composition (\%) } \\
\hline Moisture & $67.56 \pm 0.75$ \\
\hline Crude Protein & $19.94 \pm 0.13$ \\
\hline Crude Fat & $16.05 \pm 0.51$ \\
\hline Crude fibre & $2.83 \pm 0.05$ \\
\hline Ash & $2.98 \pm 0.01$ \\
\hline Total carbohydrate & $58.14 \pm 0.40$ \\
\hline Energy (Kcal) & $457.19 \pm 2.73$ \\
\hline \multicolumn{2}{|l|}{ Sugars $(\%)$} \\
\hline Total soluble sugars & $11.40 \pm 0.06$ \\
\hline Reducing sugars & $5.32 \pm 0.45$ \\
\hline Non reducing sugars & $6.08 \pm 0.37$ \\
\hline Starch & $20.21 \pm 0.30$ \\
\hline \multicolumn{2}{|l|}{ Digestibilities } \\
\hline Starch digestibility (mg maltose released/g meal) & $55.55 \pm 0.45$ \\
\hline Protein digestibility $(\%)$ & $67.56 \pm 0.90$ \\
\hline \multicolumn{2}{|l|}{ Mineral content (mg/100gm) } \\
\hline Phosphorus & $383.01 \pm 4.69$ \\
\hline Calcium & $481.02 \pm 0.02$ \\
\hline Iron & $8.79 \pm 0.95$ \\
\hline Zinc & $1.61 \pm 0.06$ \\
\hline \multicolumn{2}{|l|}{ HCl extractable minerals (mg/100gm) } \\
\hline Phosphorus & $367.66 \pm 8.23$ \\
\hline Calcium & $394.66 \pm 2.30$ \\
\hline Iron & $8.59 \pm 0.32$ \\
\hline Zinc & $1.19 \pm 0.13$ \\
\hline \multicolumn{2}{|l|}{ Per cent extractability } \\
\hline Phosphorus & $95.82 \pm 0.45$ \\
\hline Calcium & $82.04 \pm 2.59$ \\
\hline Iron & $97.72 \pm 11.04$ \\
\hline Zinc & $74.07 \pm 7.13$ \\
\hline Total Lysine $(\mathrm{g} / 16 \mathrm{gN})$ & $10.31 \pm 0.41$ \\
\hline Viscosity (cp) & $193.66 \pm 3.48$ \\
\hline
\end{tabular}

Values are mean \pm SD of three independent determinations.

Fig.1 Sensory evaluation of developed weaning food by lactating mothers

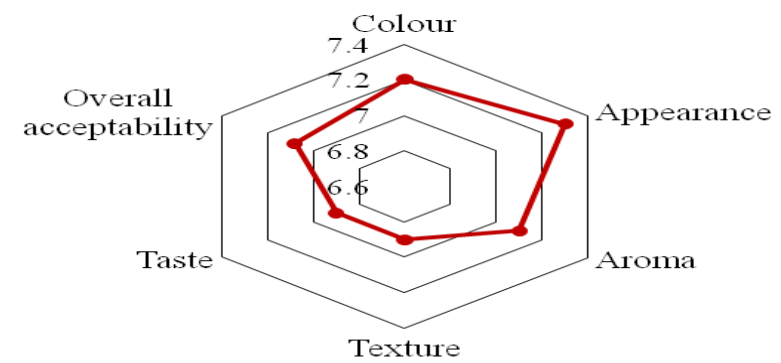


Abioye et al., (2011) reported development of soy-plantain flours. Francis et al., 2013 developed blends based on sweet potato. Mishra et al., (2014) developed weaning blends from pulse, banana and pineapple pomace while Kumari and Sindhu (2016) reported development of weaning foods from sorghum-mungbean blends incorporating banana flour.

The developed composite flours were used as base to develop weaning foods. It was found that $80 \mathrm{~g}$ of either skim milk powder/whole milk powder and $48 \mathrm{~g}$ of sugar per hundred gram of each of composite flour when cooked in $800 \mathrm{ml}$ of water resulted in weaning foods of acceptable consistency and taste. The weaning foods thus obtained were subjected to sensory analysis. All such developed weaning foods were found to be acceptable. The most acceptable weaning food was subjected to sensory evaluation by lactating mothers. Overall acceptability of weaning food ranged from "liked moderately" to "like very much". Nutritional analysis of developed weaning food revealed a good nutritional profile. Various other workers have reported development and sensory evaluation of weaning foods. Asma et al., (2006) reported that mean scores for sensory attributes of sorghum-pigeon pea blends were significantly $(\mathrm{p} \leq 0.05)$ brighter in color and had a better flavor than sorghum-cowpea blends. Nwazklor et al., (2014) prepared the weaning food from sorghum, soybean and plaintain flour and determined the mean scores of the sensory evaluation based on the sensory attributes taste, texture, colour, flavour and general acceptability. Sample with the ratio of $400 \mathrm{~g}$ sorghum, $50 \mathrm{~g}$ soybean and $50 \mathrm{~g}$ of unripe plantain had the highest mean score and general acceptability. Ikujenlola and Adurotoye (2014) evaluated the quality characteristics of high nutrient dense complementary food from mixtures of malted Quality Protein Maize and Steamed
Cowpea. All the samples were acceptable to the nursing mothers who served as the panelists.

Similar work has previously been reported by various other workers. Imtiaz et al., (2011); Ghasemzadeh and Ghavidel (2011); Khatun et al., (2013) and Ijarotimi and Keshinro (2013) have also reported sensory and nutritional evaluation of developed weaning foods.

The combination of malted sorghum, blanched soybean, blanched banana flour provided suitable base for development of weaning food. The developed weaning food exhibited a good nutrient profile. All the developed composite food mixes and weaning foods were acceptable to the panel of judges as well as to the lactating mothers. The processing methods used for development of weaning foods can be used at domestic scale by mothers.

\section{References}

Abioye, V.F., Bio, A.O., Babarinder, G., and Adesigbin, M.K. 2011. Chemical, physico-chemical and sensory properties of soy-plantain flour. Afr. J. Food Sci., 5: 176-180.

Agu, R.C., Palmer, G.H. 1997. The effect of temperature on the modification of sorghum and barley during malting. Process Biochem., 32: 501-507.

AOAC. 2000. Official Methods of Analysis.16th Ed. Association of Official Analytical Chemists. Arlyngton, Verginia, USA.

Asma, A.M., Fadil, E.B., and Tinay, A.H. 2006. Development of weaning food from sorghum supplemented with legumes and oil seeds. Food Nutr. Bull., 27: 233-235.

Balasubramanian, S., Kaur, J., and Singh, D. 2014. Optimization of weaning mix based on malted and extruded pearl 
millet and barley. J. Food Sci. Technol., 51: 682-690.

Bhatia, J., and Greer, F. 2008. Use of Soy Protein-Based Formulas in Infant Feeding. Pediatrics, 121: 1062-69.

Clegg, K.M. 1956. The application of anthrone reagent to the estimation of starches in cereals. J. Sci. Food Chem. Agri., 7: 40-44.

Cole, G.D., Wratten, S.D. and Porter, J.R. 2016. Food and nutritional security requires adequate protein as well as energy, delivered from whole-year crop production. Peer J., 4: 2100.

Dykes, L., and Rooney, L.W. 2007. Phenolic compounds in cereal grains and their health benefits. Cereal Food World, 52: 105-111.

Ghasemzadeh, R., and Ghavidel, R.A. 2011. Processing and assessment of quality characteristic of cereals - legumes composite weaning foods. IPCBEE, 5: 357-359.

Ijarotimi, O.S., and Keshinro, O.O. 2013. Formulation and Nutritional Quality of Infant Formula Produced from Popcorn, Bambara Groundnut and African Locust Bean Flour. J. Microbiol. Biotechnol. Food Sci., 1: 1358-1388.

Ikujenlola, A.V. and Adurotoye, E.A. 2014. Evaluation of Quality Characteristics of High Nutrient Dense Complementary Food from Mixtures of Malted Quality Protein Maize (Zea mays L.) Steamed Cowpea (Vigna unguiculata). J. Food Process. Technol., 5: 291.

Ikujenlola, V.A., and Fashakin, J.B. 2005. The physico-chemical properties of a complementary diet prepared from vegetable protein. J. Food Agri. Environ., 3(4): 23-26.

Imtiaz, H., Uddin, B., and Gulzar, M.A. 2011. Evaluation of weaning foods formulated from germinated wheat and mungbean from Bangladesh. Afr. $J$. Food Sci., 5: 897-903.
Khatun, H., Haque, M.R., Hosain, M.M. and Amin, M.H.A. 2013. Evaluation of Weaning Foods Formulated from Germinated Wheat and Lentil Flour from Bangladesh. Bangladesh J. Res., 8: 152-158.

Kulkarni, K.D., Jadhav, R.R., Ingle, U.M., Kulkarni, D.N. and Acharya, H.S. 1984. Induced malting of sorghum and malt utilization: Standardization of malting conditions. In Proceedings of the Vth Indian Convention of Food Science and Technology, Mysore.

Kumari, V. and Sindhu, S.C. 2016. Development of malted sorghummungbean-banana composite flours. Annals Biol., 32(2): 286-289.

Lindsey, W.L., and Norwell, M.A. 1969. A new DPTA_TEA soil test for zinc and iron. Agron. Abstract, 61: 84.

Mertz, E.T., Kiresis, A.W., Sxtell, J.D. 1983. In vitro digestibility of protein in major food cereals. Federation Process., 32: 6029.

Mishra, G., Mishra, A.A., Shukla, R.N. 2014. Development of pulse, banana and pineapple pomace based weaning food and its quality evaluation during storage. Int. J. Develop. Res., 4: 12571262.

Miyahara, S. and Jikoo, K. 1967. Examination of the Method of Colorimetric Determinatioa of Lysine. Nippon Shokuhin Kogyo Gakkaishi, 14(11): 512-513.

Nwazkalor, Chizoba, N., Obi Chioma, D. 2014. Formulation and Sensory Evaluation of Sorghum Based Weaning Food Fortified with Soybean and Unripe Plantain Flour. Int. J. Nutr. Food Sci., 3: 387-390.

Obatolu, V.A., and Cole, A.H. 2000. Functional property of complementary blends of soybean and cowpea with malted or unmalted maize. Food Chem., 70: 147- 153. 
Peterson, W.H., Skinner, J.T., and Strong, F.M. 1943. In Elements of biochemistry. Prentice Hall, New York.

Rasane, P., Jha, A., and Kumar, A. 2015. Reduction in phytic acid content and enhancement of antioxidant properties of nutri cereals by processing for developing a fermented baby food. $J$. Food Sci. Technol., 52: 3219-3234

Rastogi, A., and Singh, G. 1989. Effect of addition of full fat soyflour of different varieties on quality characteristics and bread making quality of wheat flour. Bull. Grain Technol., 27: 26-34.

Rooney, L.W., and Dykes, L.W. 2000. Phenolic compounds in cereal grains and their health benefits. Cereal Food World, 52: 105-111.

Sheoran, O.P., Tonk, D.S., Hasija, R.C., and Pannu, R.S. 1998. Statistical Software Package for Agricultural Research, Workers in Recent Advances in
Information Theory, Statistics and Computer Application. Eds. Hooda DS and Hasija RC.pp. 139-143, 6026-6028.

Singh, U., Khetar, M. S., and Jambunathan, R. 1982. Studies on desi and kabuli chickpea cultivars: The level of amylase inhibitors, level of oligosaccharides and in vitro starch digestibility. J. Food Sci. Technol., 47: 510.

Somoygi, M. 1945. A new reagent for the determination of sugar. J. Biochem., 5: 160-161.

Yemm, E.W., and Willis, A.J. 1954. The estimation of carbohydrates in plant extract by anthrone. J. Biochem., 57: 508.

Zhang, P., Whistler, R.L., BeMiller, J.N., and Hamaker, B.R. 2005. Banana starch: production, physical properties and digestibility - a review. Carbohydrates Polymers, 59: 443- 458.

\section{How to cite this article:}

Varsha Kumari, Sangeeta C. Sindhu and Jyoti Singh. 2017. Nutritional Evaluation of Indigenously Developed Weaning Food from Malted Sorghum Incorporated with Soybean and Raw Banana Flour. Int.J.Curr.Microbiol.App.Sci. 6(6): 1264-1271. doi: https://doi.org/10.20546/ijcmas.2017.606.148 